\title{
LXVI. Description of the vulture of Pondicherry
}

\section{F.M. Daudin}

To cite this article: F.M. Daudin (1804) LXVI. Description of the vulture of Pondicherry, Philosophical Magazine Series 1, 17:68, 359-360, DOI: 10.1080/14786440408676433

To link to this article: http://dx.doi.org/10.1080/14786440408676433

曲 Published online: 18 May 2009.

Submit your article to this journal $\pi$

Џ Article views: 2

Q View related articles $₫$ 
the cxposed surface will become comparatively dull; and on removing the varnish from the other parts they will appear to have undergone some process by which they have received a higher polish than glass usually exhibits : for the parts acted upon, though really dulled a little, will still appear transparent if the process has not been carried too far.

\section{Description of the Fulture of Pondichery. By F. M. DAUDiN *.}

$I_{\mathbf{T}}$ is not only easy to separate the vultures from other birds of prey because they have the head or neck bare of feathers, but they may be subdivided also into several sections, as some of them have caruncles while others are unprovided with them.

The most remarkable species are met with among those of the first section, but the one which hitherto scems most worthy of the attention of omithologists is the Oricou valture, discovered by Levaillant in Africa; for the aperture of its ears is surrounded by a membranous caruncle, four lines in height, nearly similar to an external ear, and which descends downwards on each side of the neck. The head and neck of this bird, very well preserved, may be seen in Levạillant's collection.

Sonnerat also discovered at Pondicherry another vulture so similar to the oricou in size, dimensions, and principal characters, that several naturalists have been of opinion that this vulture of Bengal might be the fcmale of the oricou, for on each side of the neck and a little below the car it has a membranous caruncle turned downwards; but as these two vultures exhibit other differences more striking 1 have thought it proper to consider these birds as two kindred species $t$.

The vulture of Pondicherry differs trom the oricou described by Levaillant, 1st, By its caruncles, which arc placed below the ear: 2d, By its face, furnished with stift hairs, which surround the iympanum, cover the checks, and are proportionably longer thin on the ncck : 3d, By its breast, covered with ash-coloured silvery down, short and compact; 4 th, by the white clowny cravat placed on each side

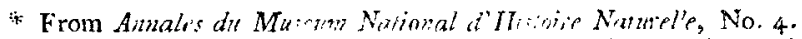

+ Levaillant, Histoire Naturclle des Oi eaux d Afrqui, pl. 9. Daudin, Traité d'Onithologie, vol. ii. pi. 1o. Vautour Oricou (Falim: auri-ularis), p. 1x. Vautour de Pondirherry (Fuling ponticerianus). 
of the lower part of the neck : 5th, By the plumes of the whole lower part of the body, which are very short, and not long and unravelled as in the oricou.

The rest of the plumage is of a very dark colour; the bill and feet are yellow.

The individual from which the annexed engraving was taken (Plate $\mathrm{X}$.) is now in the National Museum at Paris, and was found in India by Massé, the naturalist. The description published by Sonnerat is completely applicable to the individual found by Massé ; but the figure is so incorrect that Mauduyt did not venture to mention the caruncles of the neck in his Dictionnaire Ornithologique.

\title{
LXVII. Tuelfth Communication from Dr. Thonnton, on Pneumatic Medicine.
}

\author{
To Mr. Tilloch. \\ SIR, \\ No. s, Hinde-street, \\ Manchester-square.
} I Am happy to inform the philosophic world that the pneumatic practice is at this time advancing. I am credibly informed that Dr. Baillie and Dr. Reynolds, physicians equally distinguished for science and humanity, have each ordered the administration of the vital air. Several other practitioners are following the same liberal course; and it is probable that this century will sce the completion of my ardent wishes; namely, the establishment of the virtues of the aërial remedies.

The First Case of the Application of Vital Air.

To Dr. Thornton.

DEAR SIR,

Conduit-Street, Jan. 12,1804 .

In compliance with your request, I sit down to state to you the case of Mrs. L_, the lady of - E_, Esq. living near Guildford. This lady laboured under a decline, at a time when her busband was attending a course of Dr. Priestley's discovcries, nearly thirty years ago, at my lecture-rooms, then in George-Street, Hanover-Square, soon after those discoveries were made. The atrophy kept on increasing for some time after, till her state made an eminent physician of Guildford desire Mr. L- " to prepare for the worst." This alarm induced him to ask his physician, "if some of those newly discovered airs might not be usefully employed in her case." His answer was: "Any thing might be tried, but he feared all would be to 
Philo.Mag.Pl.X .Vol.XVII.

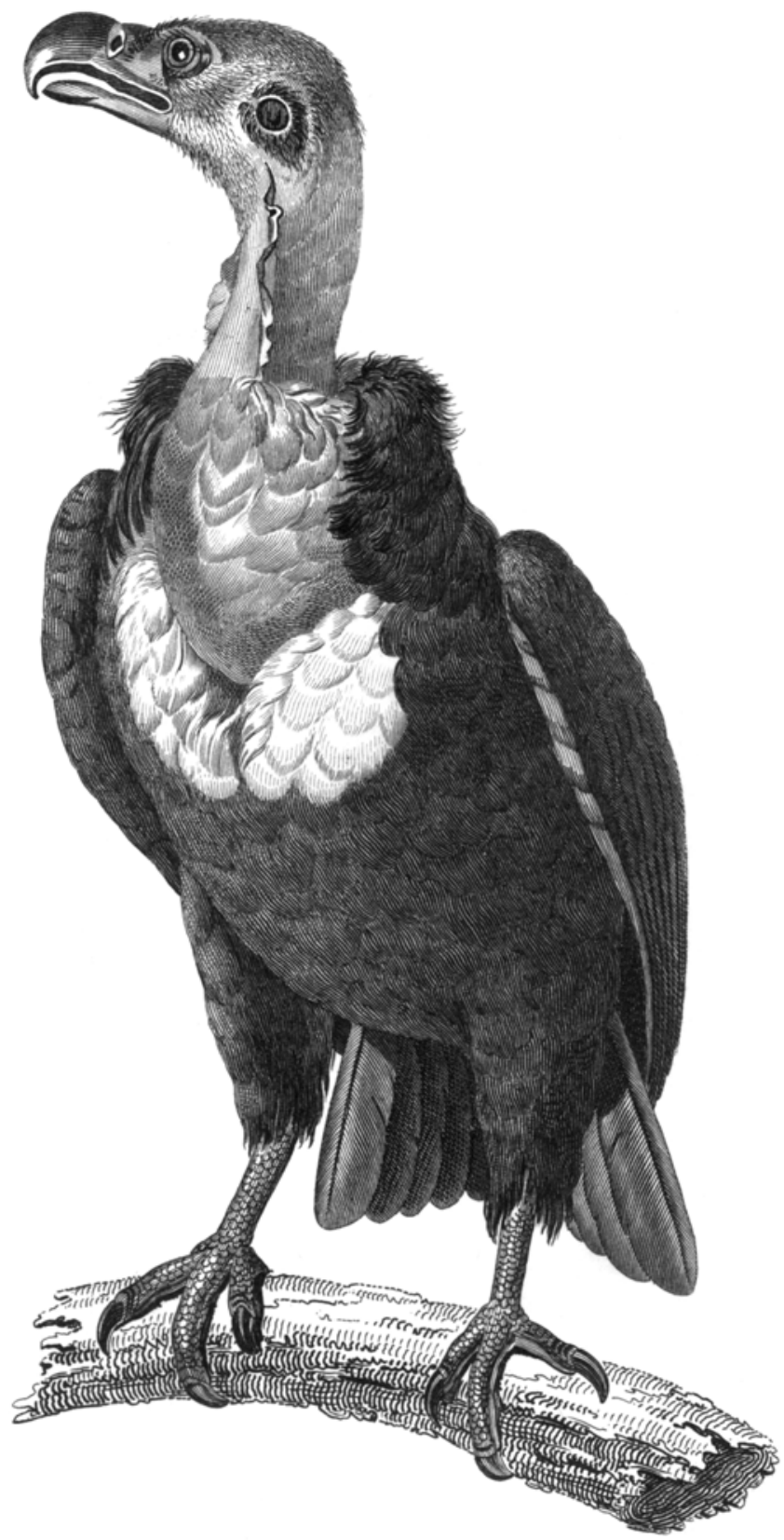

TULTURE OF PONDICHERRY. 